\title{
CONVERSATIONS WITH THE COMMON LAW: EXPOSURE, PRIVACY AND SOCIETAL CHANGE
}

\author{
N A Moreham*
}

This is an edited version of an inaugural professorial lecture delivered at the Faculty of Law, Te Herenga Waka - Victoria University of Wellington on 16 March 2021 (the promotion to professor having taken place on 1 January 2019). In the address, Professor Moreham asked what the development of new torts of privacy over the last two decades has told us about the way in which common law both shapes and responds to changing societal values. Reflecting on her own experience "growing up with" the privacy torts, Professor Moreham considered the role of the legal academic in common law development and showed how conversations between the common law and the society it serves enrich both parties to it.

\section{INTRODUCTION}

The starting point for this inaugural lecture was always going to be my two legal loves: the common law and privacy (more specifically, common law protection against unwanted exposure). The reason that I am delivering this inaugural lecture, rather than practising law as I had always intended, is that since the late 1990s these two interests have spectacularly converged - and the protection of privacy has been at the cutting-edge of common law development ever since. In the course of two decades, we have gone from having no or very little specific privacy protection in either New Zealand or England and Wales to a situation where the privacy torts are being applied, in the case of England and Wales at least, in dozens of cases a year. Given that the mid-1990s was also when I first studied law, including the law of privacy, it is no exaggeration to say that I have grown up with the privacy torts.

In this address, I want to talk about that process; the interweaving of my legal career with the development of privacy protection in New Zealand and English common law. I will also offer reflections on some of the ways the common law can respond to and effect societal change - and of the role of the legal academic in that process.

* Professor of Law, Te Herenga Waka | Victoria University of Wellington. 


\section{A BRIEF INTRODUCTION TO THE COMMON LAW}

Before I develop these themes further, I want to pause to give a brief - and highly simplified explanation of what the common law is and how it operates. At its most basic, common law is judgemade law; the law of the courts. It is not written down in a statute; Parliament did not enshrine it. Rather, it is law that has been built up over centuries by judges deciding which of the two parties in front of them should win the legal dispute in question. Each time judges do this, they give reasons for why they reached the conclusion they did. It is these reasons - or at least particular parts of them that make up the content of the common law.

To illustrate, let us imagine that my friend D sued me because I published without his consent a personal letter which he had written to me. The judge in that case decided that D should be successful in that action and gave detailed reasons for her conclusion. The next time someone was sued for publishing someone's letter without their consent, the judge would go back to that decision to see how it was decided. So if $\mathrm{G}$ published a letter from $\mathrm{C}$ in similar circumstances, then the doctrine of precedent would mean that $\mathrm{C}$ should win that case too.

It might be difficult to see how anything could change in a precedent-focused system like this but it does because, in reality, things rarely happen exactly the same way twice. Let us assume, for example, that a couple of months after the $\mathrm{D}$ and $\mathrm{N}$ decision, $\mathrm{G}$ published a personal letter written by $\mathrm{C}$ but this time he was not the intended recipient of the letter; rather, he picked it up off the street after $\mathrm{C}$ dropped it as she was walking along. Now the court has to decide how to apply the principles of the $\mathrm{D}$ and $\mathrm{N}$ decision in this slightly different situation.

This is the point at which things get contestable. One court might say that the essential basis for liability in the case between $\mathrm{D}$ and $\mathrm{N}$ was the relationship of trust and confidence between us and that when I published the letter, I was breaching that trust and confidence. Because that relationship was missing in the $\mathrm{G}$ and $\mathrm{C}$ situation, if this was the focus, C's action would be unsuccessful. Alternatively, a court might say that whilst it was clearly relevant that I published the letter in breach of D's confidence, the real wrong in the $\mathrm{D}$ and $\mathrm{N}$ situation was the fact that, by publishing the letter, I revealed to the world private information about $\mathrm{D}$. So on this approach - which is more of a privacy analysis - it does not matter that there was no relationship between $\mathrm{C}$ and $\mathrm{G}$. Because the letter $\mathrm{G}$ published contained personal information about $\mathrm{C}$, she can still recover. So there is a fresh value call in the $\mathrm{C}$ and $\mathrm{G}$ case: do the courts emphasise the breach of confidence or do they emphasise the breach of privacy? This is how change can take place even when courts are applying previous decisions.

There is a second feature of the common law that should be mentioned before I discuss the common law's interactions with the society it serves; namely, that it is common for judgments to include concepts like "reasonableness" which appeal directly to societal values. In fact, the requirement that the claimant has a "reasonable expectation of privacy" lies at the core of the New 
Zealand and English torts of privacy. ${ }^{1}$ In New Zealand, this requirement - and a second requirement that the publicity given to the information would be "highly offensive to an objective reasonable person"2 - was established by the majority of the Court of Appeal in Hosking v Runting. ${ }^{3}$ In that case, the broadcaster Mike Hosking applied for an injunction to prevent New Idea magazine from publishing photographs of his 18-month-old daughters being wheeled down an Auckland shopping street. Although the claim was unsuccessful, the majority accepted that there should be a tort of giving publicity to private facts in New Zealand. In his concurring judgment, Tipping $J$ discussed the meaning of reasonableness, explaining that it is an appeal to social norms: ${ }^{4}$

What expectations of privacy are reasonable will be a reflection of contemporary societal values and the content of the law will in this respect be capable of accommodating changes in those values.

In other words, references to "reasonableness" require courts to consider contemporary societal values when deciding the justice of the privacy case before them. As will be discussed below, these considerations can incorporate a range of matters including, in modern Aotearoa, Māori values and tikanga. $^{5}$

So, to return to my summary, the common law is a bottom-up system of law that is capable of change even whilst kind of remaining the same. In the rest of this talk, I will analyse three ways in which change in the common law takes place, focusing particularly on the role of both societal values and the legal academic in that process. I will identify three "conversations" between common law and the society it serves (acknowledging that there might also be others): in the first, the academic takes on the role of a campaigner, seeking to articulate an under-recognised societal value; in the second, commentators try to unearth values lying hidden within the common law itself; and in the third, they search for principle and coherence within actions which have already been discovered.

1 See Campbell v MGN Ltd (No 2) [2005] UKHL 61 at [21] per Lord Nicholls, [96] per Lord Hope and [134] per Baroness Hale; Hosking v Runting [2005] 1 NZLR 1 (CA) at [117] per Gault and Blanchard JJ and [249] per Tipping J; and $C v$ Holland [2012] NZHC 2155, [2012] 3 NZLR 672 at [94].

2 Hosking $v$ Runting, above $\mathrm{n}$ 1, at [117] per Gault and Blanchard JJ and $C v$ Holland, above $\mathrm{n} 1$, at [94]. Compare Hosking $v$ Runting above $\mathrm{n} 1$, at [256] per Tipping J; Rogers $v$ Television New Zealand Ltd [2007] NZSC 91, [2008] 2 NZLR 277 at [25] per Elias CJ; and Television New Zealand Ltd (TVNZ) v Rogers [2007] 1 NZLR 156 (CA) at [122] per Young J. See also N A Moreham "Abandoning the 'High Offensiveness' Privacy Test" (2018) 4 CJCCL 1.

3 Hosking $v$ Runting, above $\mathrm{n} 1$, at [117].

4 At [250].

5 Discussion of the integration of tikanga into the law of privacy is beyond the scope of this lecture. For further analysis of tikanga and privacy generally, see K Quince "Māori Concepts and Privacy" in S Penk and R Tobin (eds) Privacy Law in New Zealand (2nd ed, Thompson Reuters, Wellington, 2016) 29 at 29. 


\section{THE CONVERSATIONS}

\section{A Campaigning: Articulating a Societal Need}

In the first "conversation" between the common law and wider society, the academic takes on the role of, what could loosely be called, a campaigner. In other words, the academic - through writing, presentations and wider public engagement - encourages those developing the common law to recognise and respond to an under-protected societal need. This can happen in a variety of ways: by defining the need or problem, showing why it is important, showing why and how it can be addressed and so forth.

This is where the privacy conversation was when I first encountered it in the mid-1990s in an undergraduate media law course taught by Professor John Burrows and Professor Ursula Cheer (as she now is) at the University of Canterbury. Those were pre-Internet days, but the British tabloids were in their heyday - even less constrained in their behaviour than they are now. Think of the hounding of Princess Diana; the salacious and gratuitous outing of gay MPs and other public figures; revelations of affairs, not just by celebrities, but everyday people as well; and unchecked paparazzi intrusion, including infamously, by two photographers who photographed 'Allo 'Allo actor Gordon Kaye lying in a hospital bed with a serious head injury. ${ }^{6}$

Part of the reason this was able to go on was because legally privacy was still very much in the shadows. What I learnt in that introduction to media law (and in the Honours dissertation I later undertook under Professor Burrows' supervision) was that, in New Zealand, there had been a few bold High Court judgments recognising privacy's importance ${ }^{7}$ but that privacy had failed to make its way into the Bill of Rights Act 1990 and there was limited societal discourse about its importance. In England and Wales, there were also some bold common law steps being taken ${ }^{8}$ but recommendations for greater protection for privacy had been rejected time and time again. ${ }^{9}$ Politicians knew it was more than their careers were worth to upset the immensely powerful tabloid press who were, as a rule, unreceptive to suggestions that their freedom to publish privacy-infringing material should be constrained.

6 See Kaye v Robertson and another [1991] FSR 62 (CA).

7 See for example $P$ v D [2000] 2 NZLR 591 (HC); Bradley v Wingnut Films Ltd [1993] 1 NZLR 415 (HC); and Tucker v News Media Ownership Ltd [1986] 2 NZLR 716 (HC).

8 See for example Attorney-General v Guardian Newspapers Ltd (No 2) [1990] 1 AC 109 (HL) [Spycatcher]; Kaye $v$ Robertson and another, above n 6; Khorasandjian v Bush [1993] QB 727; Creation Records and others v News Group Newspapers Ltd [1997] EMLR 444 (Ch); and Shelley Films Ltd v Rex Features Ltd [1994] EMLR 134 (Ch).

9 See for example M Littman and P Carter-Ruck Privacy and the Law: A Report by Justice (London 1970); Report of the Committee on Privacy (chaired by Kenneth Younger, Cmnd 5012, 1972); and Report of the Committee on Privacy and Related Matters (chaired by David Calcutt QC, Cm 1102, 1990). 
All this piqued my interest straight away. I found it concerning that neither the legislature nor the common law seemed able to respond effectively to this gratuitous commodification of people's lives, particularly when those people were innocent of any wrongdoing and sometimes even injured, vulnerable or traumatised. It seemed that the way that people were being used - not treated as people but as things whose personal traumas and secrets could be laughed at or made money out of - was at least as harmful as other wrongs the law was willing to remedy.

One of the strongest objections to the recognition of privacy protection around this time was the argument that the interest was "impossible to define" and that, as a result, the scope of any legal action would be uncertain. ${ }^{10}$ This refrain was repeated by lawmakers all over the Commonwealth and it did a great deal to arrest the development of the action, particularly given the well-articulated right to freedom of expression on the other side of the argument. But - and this is the example I want to give of the academic as campaigner - throughout the 1960s, 1970s and 1980s, a group of philosophers and jurists quietly undermined this "privacy cannot be defined" premise by simply getting on and defining it.

In the second half of the last century, William Prosser's famous articulation of a four-part privacy tort was accepted in most states of the United States of America. ${ }^{11}$ At roughly the same time, an implied right to privacy in the American Constitution provided the basis for Supreme Court interventions on access to contraception and abortion services. ${ }^{12}$ This gave rise to a flurry of writing in that jurisdiction about what privacy is and why it is important. Although they did not always agree, those writers were helping to construct a language with which privacy interests could be analysed and described and with which advocates could argue for its importance. The theorist Richard Parker nicely captured this enterprise when he explained that, in his own work, he was looking for a definition of privacy that "fits the data" - meaning that it should reflect "our shared intuitions of when privacy is or is not gained or lost". ${ }^{13}$ In other words, he (and the other theorists) were trying to articulate a value which people intuitively understood and felt was important but had not yet fully put into words. This is important because, if we are going to protect an interest in the law, we need language to identify precisely what it is and why it matters.

10 See for example Geoffrey Palmer "Privacy and the Law" [1975] NZLJ 747; and R Wacks "The Poverty of 'Privacy"' (1980) 73 LQR 76.

11 The four torts are: unreasonably intruding upon the solitude and seclusion of another; appropriating another's name or likeness; unreasonably giving publicity to another's private life; and being responsible for publicity which unreasonably places the other in a false light before the public. See Restatement of the Law of Torts Volume 1 (2nd ed, American Law Institute, Minnesota, 1977) section 652A et seq; and W Prosser "Privacy" (1960) 48 Cal LR 383.

12 Griswold v Connecticut 381 US 479 (1965); and Roe v Wade 410 US 113 (1973), 93 SCt 705, 35 L Ed 2d 147 (1973).

13 R Parker "A Definition of Privacy" (1974) 27 Rutgers LRev 275 at 276. 
So what were these theorists saying? I first engaged with that question on another stage of my career growing up with the privacy torts; in 1999, when I began my PhD at the University of Cambridge. My thesis had the working title "Privacy in the common law", even though at that point there was no express recognition of privacy in the common law anywhere in the Commonwealth. ${ }^{14}$ And it was supervised by the late Tony Weir, a generous yet exacting supervisor who had a reputation as a formidable critic even when he did not think of the student's enterprise as flawed - which he did with the protection of privacy. (As his Trinity College obituary attests, "Tony's supervision style could be intimidating for the faint of heart ...")

Tony Weir's scepticism about the wisdom of writing a thesis on the common law of privacy fortified me in the view that my first job in doing so was clearly defining what privacy meant and why it was important. Drawing on the work just described - the writing of people like Ruth Gavison, Stanley Benn, Edward Bloustein, Charles Fried and Jeffrey Reiman ${ }^{15}$ - I decided that what we mean when we talk about privacy in this context is freedom from unwanted access to our physical bodies and to information about ourselves. ${ }^{16}$ In order to protect this, people need an ability (subject to reasonable limits) to retreat from the enquiry and observation of others if and when they want to. That "freedom from unwanted access" has two core components - freedom from people finding out things about you against your wishes (informational privacy) and freedom from what I call unwanted physical access - being looked at, listened to or encroached upon physically against your wishes. ${ }^{17}$ Privacy, then, is the ability to say that sometimes you do not want to be looked at, listened to or found out about; that you want to retreat into the company of intimates or be left alone altogether.

That theoretical literature also tells us a great deal about why the protection of privacy was important - why we as a society value it. It explains that the intuitive response I had had to the exposure of people's lives in the media (now also played out online) is grounded in concern about the dignity and autonomy of the individual. ${ }^{18}$ It recognised that to look at, listen to or find out about people against their wishes - and to publish private matters about them for one's own purposes - is to

14 Although there were statutory torts in four Canadian provinces.

15 See for example R Gavison "Privacy and the Limits of the Law" (1980) 89 Yale LJ 421; S Benn "Privacy, Freedom and Respect for Persons" in J Pennock and J Chapman (eds) Privacy: NOMOS Vol XIII (Atherton Press, New York, 1971) at 1; E Bloustein "Privacy as an Aspect of Human Dignity: An Answer to Dean Prosser" (1964) 39 NYULR 962; and C Fried "Privacy" (1968) 77 Yale LJ 475; and J Reiman "Privacy, Intimacy and Personhood" (1977) 6 Phil \& Publ Aff 26.

16 See N A Moreham "Privacy in the Common Law: A Doctrinal and Theoretical Analysis" (2005) 121 LQR 628 at 636 .

17 At 639-643.

18 See for example Bloustein, above n 15; and Benn, above n 15, at 1. 
treat them as a means to one's ends. ${ }^{19}$ In one of my favourite articles, Stanley Benn articulates this by explaining why an onlooker objects to Henry Higgins recording Eliza Doolittle without her knowledge in George Bernard Shaw's play, Pygmallion. He said: ${ }^{20}$

Higgins fails to show a proper respect for persons; he is treating people as objects or specimens - like 'dirt'

- and not as subjects with sensibilities, ends and aspirations of their own ... These resentments suggest a

possible ground for a prima facie claim not to be watched, at any rate in the same manner as one watches

a thing or an animal. For this is to 'take liberties', to act impudently, to show less than a proper regard for

human dignity.

You will not find Stanley Benn's name cited in the privacy cases but I would suggest that his work, and that of others like him, was important in shifting the narrative that privacy cannot be defined or legally protected. Their ideas, and those of others like them, also clearly helped shape the legal definition of the interest. Courts both in New Zealand and England have expressly recognised that the protection of privacy is about "the dignity and autonomy" of the individual. ${ }^{21}$ And in New Zealand at least, the two components of the privacy interest which I have just described - informational and physical privacy - are reflected in the two privacy torts which the courts have recognised. As well as the tort of giving publicity to private information (affirmed in Hosking), ${ }^{22}$ New Zealand courts have recognised a tort protecting against the "intentional and unauthorised intrusion ... into seclusion (namely intimate personal activity, space or affairs)" which focuses principally on unwanted looking, listening and recording. ${ }^{23}$

The idea of retreat and inaccessibility which was central to much of this theoretical writing also provided a conceptual framework on which an exposure-focused legal action could be built. Tipping $\mathrm{J}$ (one of the judges I was lucky enough to work for as a judges' clerk not long before he and his Court of Appeal colleagues morphed into the newly-minted Supreme Court) expressed this idea particularly well in his concurring judgment in Hosking. He said: ${ }^{24}$

19 A Kantian idea: see for example I Kant Grounding for the Metaphysics of Morals: with On a Supposed Right to Lie Because of Philanthropic Concerns (J Ellington (translator), 3rd ed, Hackett Publishing Company, Indianapolis, 1993) at 428 .

20 Benn, above $\mathrm{n} 15$, at 6-7.

21 See for example Campbell v MGN Ltd (No 2), above n 1, at [50]-[51] per Lord Hoffman; Hosking v Runting, above n 1, at [239] per Tipping J; and Brooker v Police [2007] NZSC 30, [2007] 3 NZLR 91 at [182] and [252] per Thomas J.

22 Hosking $v$ Runting, above $\mathrm{n} 1$.

23 See $C v$ Holland, above n 1, at [94]; Graham v Queen [2015] NZCA 568 at [22] et seq; and N A Moreham "A Conceptual Framework for the New Zealand Tort of Intrusion" (2016) 47 VUWLR 283.

24 Hosking $v$ Runting, above $\mathrm{n} 1$, at [239]. 
It is of the essence of the dignity and personal autonomy and well-being of all human beings that some aspects of their lives should be able to remain private if they so wish. Even people whose work, or the public nature of whose activities make them a form of public property, must be able to protect some aspects of their lives from scrutiny.

Inaccessibility then - along with the protection of physical and informational privacy - had made its way into the New Zealand common law. Albeit indirectly, the campaigning had had an impact.

\section{B Identifying Values Lying Unarticulated in the Common Law}

So that is the first conversation society has with the common law - one in which the academic acts as an advocate for greater recognition of a particular societal value. The second conversation focuses more on the content of the law itself. In this conversation, academics, judges and lawyers delve into the common law to discover principles - which usually reflect wider societal values - lying dormant within it.

So how does this happen? As already discussed, the common law is a bottom-up jurisprudence where judges are principally concerned with a just outcome for the parties in the case before them. Judges always give reasons for their conclusions, however, and over time the collective wisdom of those reasons builds up into principles and legal rules. Usually these rules and principles are obvious, but sometimes there is a slight bend in the road which will only be perceived if you look for it carefully. And sometimes, once you spot it, you see that this little bend can take the law off in a whole new direction. Lawyers will be able to think of situations where these new roads have been "discovered" in the past - the principles of negligence early last century, judicial review in the 1950s and 1960s, restitution in the 1980s and 1990s, and now, privacy.

Throughout the decades, the importance of privacy has been implicitly recognised in various common law actions. It has been incidentally protected, for example, in nuisance, malicious falsehood, defamation, trespass to the person, trespass to goods and land, and in cases involving copyright in photographs, letters and other papers. ${ }^{25}$ Most significantly, it has been protected in breach of confidence. As mentioned in connection with my hypothetical disclosure of D's letter, the focus of the breach of confidence action has traditionally been on the circumstances in which information has been disclosed by one party to another. The action, therefore, had three main requirements: that the information in question was confidential (ie, it was not generally known); that the information was imparted in circumstances giving rise to an obligation of confidence; and the information was used to

25 See respectively Khorasandjian v Bush, above n 8; Kaye v Robertson, above n 6; Youssoupoff v MetroGolden-Meyer Pictures Ltd (1934) 50 TLR 581 (CA); Collins v Wilcock [1984] 1 WLR 1172 (QB); Robson $v$ Hallett [1967] 2 QB 939 at 954 per Diplock LJ; and Pollard Photographic Co (1888) 40 ChD 345. See generally N A Moreham and M Warby The Law of Privacy and the Media (3rd ed, Oxford University Press, Oxford, 2016) at 10.04-10.45. 
the detriment of the confider. ${ }^{26}$ These requirements were traditionally satisfied where the parties were in an ongoing relationship of confidence (like doctor/patient, lawyer/client or in the private domain, husband and wife). ${ }^{27}$ But, because of the type of information usually confided within these relationships, protection of them went a long way towards protecting private information itself. ${ }^{28}$ If a newspaper published personal information contained in a heartfelt letter I had written to a friend, for example, breach of confidence would provide a remedy because of the way the information had been communicated; and that would, of course, have the incidental effect of keeping my private information out of the public domain.

Towards the end of last century, commentators, judges and lawyers started to recognise these cases' potential to fill a privacy-sized gap in the law. And the bend in the road started appearing. The second requirement of the breach of confidence action changed so that claimants simply had to show that the defendant acquired the information in circumstances where he or she knew or ought to have known that it was confidential. Lord Goff famously explained the implications of this extension in Attorney-General $v$ Guardian Newspapers Ltd (often called Spycatcher after the name of the book which a former MI5 intelligence officer was seeking to publish in the United Kingdom). He said: ${ }^{29}$

\footnotetext{
I have expressed the circumstances in which the duty [of confidence] arises in broad terms ... to include certain situations, beloved of law teachers - where an obviously confidential document is wafted by an electric fan out of a window into a crowded street, or where an obviously confidential document, such as a private diary, is dropped in a public place, and then is picked up by a passer-by.
}

In other words, breach of confidence could now provide protection simply because the information in question was "obviously confidential". The essence of liability for the disclosure of personal information was no longer the relationship between the parties when the information was disclosed; it could also be based on the nature of the information itself. That shift in focus left the door wide open to privacy protection.

26 See Coco v AN Clark (Engineers) Ltd [1969] RPC 41 (Ch) at 47:

First, the information itself, in the words of Lord Greene, MR in the Saltman case ... must 'have the necessary quality of confidence about it'. Secondly, that information must have been imparted in circumstances importing an obligation of confidence. Thirdly, there must be an unauthorised use of that information to the detriment of the party communicating it.

27 See for example Duchess of Argyll v Duke of Argyll and others [1967] Ch 302 [Argyll v Argyll] (regarding the confidentiality of the marriage relationship); and more generally F Gurry Breach of Confidence (Oxford University Press, New York, 1984) at chapter VII.

28 See for example Argyll v Argyll, above n 27; Barrymore v News Group Newspapers Ltd [1997] FSR 600 (Ch); and Lord Goff's private diary example in Spycatcher, above n 8, at 281.

29 Spycatcher, above $\mathrm{n} 8$, at 281. 
This was where English common law was when I first studied it on home ground. It just needed one last nudge to recognise that a new privacy interest had emerged from within breach of confidence; that the bend in the road had created a new cause of action. Then the nudge came. Just before I arrived at the University of Cambridge to undertake a Masters in Law in 1998, Tony Blair's Labour government had enacted the Human Rights Act 1998 (UK) (the HRA). This legislation, which came into force in late 2000, incorporated into English law the European Convention on Human Rights 1950 (the Convention). Importantly for our purposes, art 8 of the Convention confers on citizens of Member States a right to respect for private life. ${ }^{30}$ There was a huge amount of buzz about art 8 when I arrived in Cambridge, much of it focused on whether it might finally lead to the privacy protection which people had been calling for (or resisting) for so long. Commentators - academics, practitioners, judges writing extra-judicially - were pushing forward this conversation by showing not just why, but also how, this step should be taken. ${ }^{31}$

I was introduced to all this in the Cambridge LLM civil liberties course by another Canterbury graduate, Professor ATH Smith. ATH Smith is part of a long line of New Zealand law Fellows at my own college, Gonville and Caius (a line which continued when I became a Fellow there on completing my PhD) and, of course, in 2006, he became Dean of Law here at VUW. Much of the discussion in his civil liberties course was about the likely horizontal effect of the HRA on the common law. This included discussion of the argument, which English courts ultimately accepted, that the s 6 requirement that public authorities must act compatibly with the principles of the Convention meant that courts had to act compatibly with those principles when developing the common law. ${ }^{32}$ In the privacy context, this meant they had to act compatibly with the right to respect for private life when developing the law of breach of confidence. As Sedley LJ said in Douglas v Hello! (which concerned an ultimately unsuccessful application by actors Michael Douglas and Catherine Zeta-Jones to prevent

30 Article 8 provides that:

1. Everyone has the right to respect for his private and family life, his home and his correspondence. 2. There shall be no interference by a public authority with the exercise of this right except such as is in accordance with the law and is necessary in a democratic society in the interests of national security, public safety or the economic well-being of the country, for the prevention of disorder or crime, for the protection of health or morals, or for the protection of the rights and freedoms of others.

31 See for example M Hunt "The Horizontal Effect of the Human Rights Act" [1998] PL 423; H Fenwick and G Phillipson "Breach of Confidence as a Privacy Remedy in the Human Rights Act Era" (2000) 63 MLR 660; H Wade "Horizons of Horizontality" (2000) 116 LQR 217; R Buxton "Human Rights Act and Private Law" (2000) 116 LQR 48; A Lester and D Pannick "The Impact of the Human Rights Act on Private Law: The Knight's Move" (2000) 116 LQR 380; and J Beatson and S Grosz "Horizontality: A Footnote" (2000) 116 LQR 385.

32 Section 6(1) of the HRA provides that: "It is unlawful for a public authority to act in a way which is incompatible with a Convention right". 
unauthorised publication of photographs of their wedding), the HRA had given courts the "final impetus" to develop breach of confidence into a privacy action. ${ }^{33}$

For a while, the courts retained the breach of confidence label for this new privacy protection. They fused the requirements of breach of confidence and privacy together by saying that claimants had to establish a duty of confidence but that doing so depended on whether they had a reasonable expectation of privacy in the activity or information in question. ${ }^{34}$ Eventually, though, a fully-fledged tort emerged, freshly re-labelled "misuse of private information". ${ }^{35}$ The key requirement of this new tort was that the claimant had a reasonable expectation of privacy in respect of the information or activity in question. If so, the privacy interest had to be balanced against any competing right to freedom of expression (which is usually done by reference to the degree of public interest in the material in question). ${ }^{36}$

So there it was, buried in the English common law all along; the very interest that the commentators had been saying needed more protection. And it should not be surprising that they found it there given that the judges developing the common law had been operating in the same societal context as theorists defining the privacy interest. They were responding to the same social pressures and interests; the same societal trends and changes. So, it is to be expected that - whether consciously or unconsciously, directly or indirectly - those same societal values made their way into the common law as judges decided the justice of each case before them. Just as in the wider societal context, someone just needed to discover that those values were there.

All that said, I acknowledge that the influence of the Convention on the development of the English privacy action could be seen to undermine my argument that the common law had privacy buried within it simply waiting to be discovered. It is important, however, not to overemphasise the ongoing significance of the springboards which led to the privacy interest being recognised. In Douglas $v$ Hello!, Sedley LJ expressly said that, even without the HRA, privacy should have been recognised as a common law right. He said that the Court of Appeal's conclusion that a right to privacy had emerged from within the breach of confidence action was: ${ }^{37}$

to say little, save by way of label, that our courts have not said already over the years ... The law no longer needs to construct an artificial relationship of confidentiality between intruder and victim: it can recognise privacy itself as a principle drawn from the fundamental value of personal autonomy.

33 Douglas and others $v$ Hello! Ltd [2001] QB 967 at [111].

$34 A v B$ (a company) [2002] EWCA Civ 337 at [11(x)] [Flitcroft $v$ MGN Ltd].

35 See for example Murray v Express Newspapers Plc [2008] EWCA Civ 446.

36 See for example Murray v Empress Newspapers Plc, above n 35; and Campbell v MGN Ltd (No 2), above $\mathrm{n}$

37 Douglas v Hello!, above n 33, at [125]-[126]. 
That common law grounding is also reflected in the substantive development of the action. The English misuse of private information tort is far from an enactment of the Convention concept of "respect for private life". That Convention right is broad, amorphous and designed to be applied at supranational level by a supervisory international court. It is broad-brush, top-down reasoning which was never intended to be adopted wholesale into the legal system of Member States. Rather, Member States are obliged to protect the Convention interests in their own way with a broad margin of appreciation applying. ${ }^{38}$ And when it comes to the content of the interest, art 8 protects a positive, liberty-focused conception of private life which includes things as diffuse as the right to be free from unwanted photography, to live a traveller lifestyle, to access information about your adoptive parents and to be free from noise pollution. ${ }^{39}$ This bears little resemblance to the modern English misuse of private information tort. ${ }^{40}$

The New Zealand law is similar. Our courts relied heavily on US precedent when developing the requirements of the New Zealand privacy torts, ${ }^{41}$ but the content of our torts differs significantly from theirs. US cultural conditions are too different - particularly the priority given to free speech interests - for their precedents to be routinely followed in this jurisdiction. ${ }^{42}$ Instead, New Zealand courts have taken the requirements of the US torts and made them their own, fitting them into our common law and developing them consistently with our societal conditions.

Recognising that the privacy torts are embedded in the local common law like this has useful implications. First, it makes it clear that the privacy torts should not be seen as sui generis actions which can do their own thing independent of other common law principles or actions. On the contrary, in both New Zealand and England and Wales, they need to take their place amongst the common law family, developing consistently with established common law principles (about remedies, for example) and fitting in with other, more established, actions. This means that we need to be careful, now that the torts are coming of age, that they do not run roughshod over carefully drawn protections in other areas of law. English judges are currently grappling, for example, with the extent to which the privacy action should avail claimants trying to protect their reputation, the Court of Appeal having recently held that claimants will usually have a reasonable expectation of privacy in respect of the

38 See further N A Moreham "The Right to Respect for Private life in the European Convention on Human Rights: A Re-examination" [2008] EHRLR 44; and R Clayton and H Tomlinson The Law of Human Rights (2nd ed, Oxford University Press, Oxford, 2009) at [6.42]-[6.62].

39 See above $\mathrm{n} 38$

40 It should be noted, however, that claimants can bring actions against public authorities directly for breaches of the HRA and that many of the interests which fall within the Convention art 8 right are protected in this manner.

41 See Hosking $v$ Runting, above $\mathrm{n}$ 1; and $C$ v Holland, above $\mathrm{n} 1$.

42 See further Moreham and Warby, above n 25, at [3.53]-[3.61]. 
fact that they are being investigated by the police (up to the point of charge). ${ }^{43}$ But there is a real need for caution if courts are to avoid circumventing the free speech protections carefully developed over centuries in defamation. ${ }^{44}$ Privacy needs to get on with its much older defamation sibling - and with trespass while we are at it. ${ }^{45}$

Secondly, once we look past the springboards relied on to bring them into being, it becomes clear that the English and New Zealand privacy torts have more similarities than differences. Both are operating in societies which, at least as far as Pākehā values are concerned, share many cultural norms and values (including the starting point that freedom of expression does not trump other important values). And at the heart of both actions are the same central questions: did the claimant have a reasonable expectation of privacy and if so, how should that be balanced against any public interest in the information? This means that the two jurisdictions have a great deal to learn from each other particularly, it has to be said, New Zealand from England, given the much greater volume of case law in that jurisdiction.

Finally, the Conservative Party in England has for some time been threatening to abolish the HRA and even to leave the Council of Europe so that the United Kingdom is no longer bound by art 8 or any other part of the Convention. Recognising that privacy was already embedded in the common law, and that the HRA was just a springboard to help the courts bring that fact to light, helps immunise the privacy torts from the disruptive effect that a departure of this nature could have.

\section{Finding Principle and Coherence}

So, discovering a new value within the common law is the second way that legal academics, judges and lawyers effect change within the common law. The third and final conversation - which I am calling the search for principle and coherence - happens further down the track in a new action's development; it becomes more relevant as the action comes of age.

As mentioned, there are now dozens of torts cases (particularly in English law) discussing when something is private and when privacy needs to yield to a competing public interest. Unsurprisingly, analysing that case law provides valuable insight into when something will and will not be private; not just in the legal context, but in the wider societal context as well. Indeed, I have argued in my own writing that the case law shows that whether something is private can generally be determined by asking two interrelated questions. The first question looks at societal attitudes and asks whether the activity or information in question is something which most people would think the claimant should be entitled to keep to themselves. This question is heavily context-specific, but courts have said people will generally have an expectation of privacy if the exposure in question relates to things like sexual

43 ZXC v Bloomberg [2020] EWCA Civ 611. See also Richard v BBC [2018] EWHC 1837 (Ch).

44 N A Moreham "Privacy and Police Investigations: ZXC v Bloomberg" (2021) 80 CLJ 5.

45 On the latter point, see Moreham, above n 23, at 297-298. 
activity, matters to do with the naked body, health information, domestic intimacies or the inner workings of the claimant's mind. ${ }^{46}$ The second question - which is all about signals - looks at the way in which the claimant has behaved in respect of that activity or information. Did he cover that part of his body with clothes? Did she store the photos on a private device? Did he go into his house and shut the door or put some other physical barrier in front of the camera? Or conversely did the claimant post a photograph of the activity publicly on Facebook? ${ }^{47}$

It is important to identify these sorts of principles as clearly as possible because people need to know in advance, of course, how the common law will apply to them. This is particularly important when the interest being protected affects another's freedom of expression. If editors, or private individuals, are unsure about what kind of material the law of privacy protects, then important public interest disclosures can be suppressed even though the law would not in fact have sanctioned them.

This attempt to bring clarity to the common law is not, however, just an internal conversation the law does not just respond to social values, it shapes them as well. I have already described some of the ways in which the common law has responded to social discourse on privacy. It is important to emphasise, as we come to conclude, that it has pushed forward those conversations as well. Judicial recognition of privacy's importance in the common law has provided a valuable backdrop for conversations about its importance in areas outside the typical privacy tort fact-pattern - for example, in data protection, policing, border control and the workplace. It also provides valuable guidance on how the privacy interest should be understood, not just in common law but these wider societal contexts as well. Common law tells us that privacy is a mixed objective/subjective concept, grounded in the dignity and autonomy of the individual, which protects the a person's ability to determine (subject to reasonable limits) when and how he or she will be accessible to others. That wisdom has been built up in dozens of cases, all of which had benefited from detailed argument and careful analysis. It is not surprising that this provides insights which are useful in other contexts as well.

\section{CONCLUSION}

That brings us full circle. Having started with the argument that privacy was too difficult to define to form the basis of legal protection, the common law now helps define wider societal conceptions of privacy. And this brings me back to the convergence of my two legal loves. The development of the law of privacy has pushed the common law to protect an interest more subtle than it has ever protected before. This shows its ability not only to respond to social change but also to guide it, by recognising the importance of these very human interests in the face of increasingly significant threats. That is a

46 See further N A Moreham "Unpacking the Reasonable Expectation of Privacy Test" (2018) 134 LQR 651 at 657-660.

47 At 660-672. 
hugely stimulating process to have been a part of but I could not have done it - nor could I continue to do it - if I did not also believe it to be important. 
